\title{
The Value of Coproduction of Ethanol and Furfural from Acid Hydrolysis Processes
}

\author{
Stephen Parker \\ Mark Calnon \\ Daniel Feinberg \\ Arthur Power \\ Solar Energy Research Institute \\ Lawrence Weiss \\ Energy Technology Associates
}

May 1984

To be presented at the

6th Symposium on Biotechnology for Fuels and

Chemicals

Gatlinburg, Tenn.

15-18 May 1984

Prepared under Task No. 1423.10

FTP No. 153

Solar Energy Research Institute

A Division of Midwest Research institute

1617 Cole Boulevard

Golden, Colorado 80401

Prepared for the

U.S. Department of Energy

Contract No. DE-AC02-83CH10093 


\section{NOTICE}

This report was prepared as an account of work sconsored by the United States Government. Neither the United States nor the United States Department of Energy, nor any of their employees, nor any of their contractors, subcontractors, or their employees, makes any warranty, express or implied, or assumes any legal liability or responsibility for the accuracy, compieteness or usefulness of any information. apparatus, product or process disciosed, or represents that its use would not infringe privately owned rights. 


\title{
THE VALUE OF COPRODUCTION OF ETHANOL AND FURFURAL FROM ACID HYDROLYSIS PROCESSES
}

\author{
Stephen Parker, Mark Calnon, Daniel Feinberg, Arthur Power \\ Solar Energy Research Institute \\ Golden, Colorado 80401 \\ Lawrence Weiss \\ Energy Technology Associates \\ New York, New York 10168
}

\begin{abstract}
In the acid hydrolysis of a cellulosic feedstock (wood, wood wastes, or crop residues), up to $3.65 \mathrm{lb}$ of furfural may be coproduced with each gallon of ethanol for only the cost of recovering and purifying it. Each plant producing $50 \times 10^{6} \mathrm{gal} / \mathrm{yr}$ of ethanol would produce an amount of by-product furfural equal to the total current domestic production. Thus, the need arises for investigation into potentially suitable processes for deriving profitable end products from furfural and thus expanding the market.

At its current price, furfural has been confined to a few specialty solvent, resin, and chemical intermediate markets, most of which are expected to grow very slowly, if at all. At lower prices, however, furfural of fers significant promise as a chemical intermediate. The objectives of this study were to determine the economic potential of five selected, large volume derivatives of furfural that could displace hydrocarbon-based chemicals, and the consequent value of furiural as a by-product to the cellulose hydrolysis process of ethanol production. The results of the analyses of furfural potential indicate that the furfural-based processes for producing n-butanol, adipic acid, and
\end{abstract}


maleic anhydride could be economically competitive with hydrocarbon-based processes and could reduce the cost of approximately $960 \times 10^{6}$ gal of ethanol to a selling price as low as $\$ 0.91 /$ gal.

\section{INTRODUCTION}

Ethanol can potentially replace gasoline, as a neat fuel, or traditional fuel extenders and octane boosters such as methyl tertiary butyl ether (MBTE), tertiary butyl alcohol (TBA), and n-butane. However, the cost of producing ethanol by acid hydrolysis of cellulose using current technology is too high to allow competitive ethanol prices. Research and developmental work on this technology are focusing on process improvements that will reduce the price of ethanol. One line of investigation concerns the development of process schemes for the production and sale of ethanol and process by-products, such as furfural and lignin. If such multiproduct process schemes are successfully developed, the raw material value of the lignocellulosic feedstock will be higher, thereby significantly reducing ethanol production costs. The study reported in this paper focuses on determining the value of by-product furfural to the cellulose hydrolysis process for ethanol production.

\section{Study Approach}

Furfural derived from acid hydrolysis might penetrate chemicals markets by two major routes. The first route involves displacing current production of furfural. If furfural coproduced with ethanol by the acid hydrolysis of cellulose can be produced at a lower unit cost and in sufficient quantity to meet demand, it will likely displace current production. However, the existing furfural market is relatively small and growing slowly, limiting the subsidy potential of a furfural by-product credit for ethanol production. 
The second route to furfural market penetration, and the one on which we focus in this study, involves upgrading furfural to derivatives that can substitute for current petrochemical feedstocks or intermediates in the production of existing commodity chemicals. The assessment of furfural market penetration potential by this route is more difficult than assessment of the existing furfural market. One reason is that the technical and economic feasibility of the production of furfural derivatives has not been established. The other, more significant reason is that the complex, product-interrelated structure of the petrochemical industry can impose constraints on the introduction of new feedstocks or modes of production. To assess market potential we have selected, therefore, distinct yet complementary analytical methods that take into account engineering, economic, and market factors.

This study is based on the process engineering analyses of the hydrocarbon- and furfural-based routes to the production of five large-volume (minimum annual production of $\left.100 \times 10^{6} \mathrm{lb} / \mathrm{yr}\right)$ commodity chemicals: butanol, butadiene, styrene, adipic acid, and maleic anhydride. Criteria used to select these five chemicals include (1) àvailability of . well-defined process technology and capital and operating cost data for large-scale hydrocarbon-route plants, (2) availability of patent and laboratory experimental data on furfural-route processes, and (3) high probability of ultimate successful commercial-scale development of furfural-based processes. Each furfural process has a history of at least ground-breaking research work in Germany and England in the 1930s. Comparisons of the capital and operating costs for competing process options provide a preliminary indication of the potential for furfural to displace petroleum feedstocks in these markets and to subsidize the price of ethanol for fuel markets.

The cost comparisons were derived by first calculating the sales price for $15 \%$ discounted cash flow (DCF) return for the hydrocarbon-based routes. Then, for the furfural routes the raw materials costs were calculated to yield the same DCF returns as the hydrocarbon routes. Finally, the equivalent furan/tetrahydrofuran and furfural costs 
were calculated. These furfural costs, less estimated recovery costs of about $\$ 0.03 / 1 b, *$ are approximate measures of the by-product values that could be credited to the cellulose hydrolysis process for ethanol production. The results constitute a conservative base case and may be modified, if desired, for various inflation rates and future crude oil market values.

The results of this first level of evaluation, which analyzes the cost differential between the established production processes and the proposed furfural-based processes, provides an initial characterization of the competitive economics and technical feasibility. However, a competitive cost advantage for a furfural-based process will not ensure that it displaces the existing process. Complex factors inherent in the petrochemicals industry can restrict the market penetration by a new chemical feedstock. We include discussion in this paper of how the integrated structure of the petrochemical industry can be expected to affect the cost required to trigger penetration of new technologies. Then, using a model of the U.S. fuels and petrochemical industry, we examine the potential for subsidizing ethanol production with furfural by-product credits.

\section{PROCESS TECHNOLOGY}

\section{Background}

The use of furfural to produce commodity chemicals is not a subject of exclusively recent interest. Furfural was investigated in the laboratory many years ago, especially in wartime Germany in the 1930s, as an alternative feedstock for hydrocarbon-based

*Furfural recovery costs are site-sensitive because the dominant cost factor, both capital and operating, is low-pressure steam. A plant steam balance with a significant surplus of low-pressure steam is a common condition and could lead to recovery costs less than $\$ 0.03 / \mathrm{lb}$. 
commodity chemicals such as butadiene, styrene, maleic anhydride, adipic acid, adiponitrile, hexamethylenediamine, butanol, synthetic lubricant polymers, and many others. Walter Reppe and coworkers appear to have been leaders in this work, and descriptions of most of their experimental work can be found in German literature and British and American technical intelligence reports. Wartime urgency and the attendant disregard for cost kept alive interest in furfural as a versatile chemical building block. Today we have reason to revive this work because of the potential for furfural to be a largevolume, low-cost coproduct in the production of fuel-grade ethanol from the acid hydrolysis of cellulose.

In the acid hydrolysis of a cellulosic feedstock for production of ethanol, furfural can be coproduced in yields up to $60 \%$ of the hemicellulose, or about $3.65 \mathrm{lb}$ for each gallon of ethanol. A yield of $60 \%$ was used as the basis of this study. (Hydroxy methyl furfural [HMFl, another by-product of less importance, is not considered in this study.) The hydrolysis reaction conditions for producing ethanol are similar to those under which furfural is commercially prepared: temperatures are $250^{\circ}-350^{\circ} \mathrm{C}$, pressures are above $100 \mathrm{lb} / \mathrm{in}^{2}$, and dilute mineral acid (usually sulfuric but sometimes hydrochloric) is present (3). This means that furfural is produced for only the cost of recovering and purifying it. Each plant producing $50 \times 10^{6} \mathrm{gal} / \mathrm{yr}$ of ethanol would also produce an amount of by-product furfural equal to the total current domestic production. Thus, the need arises for investigation into potentially suitable processes for deriving profitable end products from furfural.

\section{Furfural: Current Status}

Furfural is the common name for 2-furaldehyde, a derivative of furan. Furfural is a widely used chemical intermediate, but unlike many chemical intermediates, a competitive hydrocarbon-based process for its production has never been found (18). Instead, it is produced from the five-carbon sugars, especially xylose, which make up $25 \%$ or more 
of the composition of various woods and crop residues. The Quaker Oats Company produces essentially the entire U.S. output, using oat hulls as the primary raw material (3). Estimates of 1980 furfural production range from $125 \times 10^{6} \mathrm{lb}$ (15). Furfural production in recent years has been only marginally profitable for Quaker Oats, and the company has publicly expressed doubts about whether it will continue to produce furfural (7). The current list price of furfural is $\$ 0.66 / 1 b$ (8).

At its current price, furfural has been confined to a few specialty solvent, resin, and chemical intermediate markets, most of which are expected to grow very slowly, if at all (e.g., steel) (15). Slight decreases in the price of furfural would directly affect its two most common derivatives, tetrahydrofuran and furfuryl alcohol. The former is an important solvent for which there is a competitive petroleum-based synthesis; the other, furfuryl alcohol is used in the manufacture of resins and binders.

Cheap furfural offers the most promise as a chemical intermediate. It can be and has been converted to a great variety of chemicals, some commercially and others in the laboratory only. Some of these derivatives have current markets many times that of furfural, and these markets will at least grow at the same rate as the economy. The five commodity chemicals selected for this study represent a good cross section of the petrochemical industry. Each is a moderately to extremely large volume commodity chemical that is currently produced from petroleum-based feedstocks but can also be made from Iurfural. Each of the furfural conversion processes has been demonstrated in the labora tory.

\section{Process Studies}

A required first step in determining the market feasibility of furfural derivatives is establishing a standardized means of comparing the furfural-based routes with the hydrocarbon-based routes producing the five chemicals selected for study. Process and economic studies performed by Energy Technology Associates (ETA) compare capital and 
operating costs of the alternative processes for large-scale manufacture of the five chemicals. These studies allow appraisal of the economics with the best process information available. In this section we present the basis and the results of the ETA process engineering studies and analyze their relevance.

The plant capacities selected are so-called "world-class" size, equal to the most recently operational plant, which is generally the largest built. Process information was obtained from published sources. Because much work is required to commercialize the furfural-based processes, the economic analyses were adjusted to the year 1995. Moderate rates of inflation were assumed for construction costs as well as for the cost of crude oil, but the real price of crude oil was assumed to remain constant.

The process studies by ETA yielded for each of the five pairs of alternatives (i.e., chemical production from hydrocarbons versus furfural) a discussion of the process chemistry, a process description, a process flow diagram, and an economic summary consisting of the following elements:

- Plant eapacity and location

- Year of costs used and stream factor

- Production costs, including use factors and unit costs:

- Raw materials

- Utilities

- Operating costs

- Overhead expenses

- Depreciation

- Sales price for $15 \%$ DCF return.

The results are sufficiently good to establish a value for furfural as a raw material that yields a profitability for the furfural process routes to each product that is approximately equal to the profitability of the hydrocarbon routes. This value represents the maximum cost that producers of the furfural derivative can afford to pay in order to 
recover their capital, as well as the credit the ethanol and furfural producer can expect to receive. These economic results are adequate for broad comparisons. Establishment of more definitive data for the individual furfural processes was beyond the scope of the work and can be done only after considerably more research, development, and engineering.

In tables for each of the five chemicals examined, we present the capital and operating costs for both the hydrocarbon and furfural-based processes to permit direct comparisons of all cost components. The sales prices (15\% DCF return) calculated for the hydrocarbon-route products were assumed to be the same for the furfural-route products. A net raw materials cost for the furfural route was calculated using this value and the capital investment estimates, which are extensions of the known hydrocarbonroute investments. This cost was then further broken down to the furan/tetrahydrofuran costs required for equal profitability of the hydrocarbon and furfural process routes; the results are shown as footnotes to the tables. We include, in addition, process flow diagrams for promising furfural-based procèsses.

n-Butanol. Table 1 compares the economics of n-butanol production via the conventional carbonylation of propylene (the oxo process) and via the proposed furan hydrogenation process. The investment costs and working capital requirements for both processes are within the same ranges. With a furan value of $\$ 0.25 / 1 b$ (a 1982 furfural value of $\$ 0.08 / 1 b)$, the production cost and selling price of butanol are identical for both processes. Even with a $310 \times 10^{6} \mathrm{lb}$ annual feedstock requirement, the net raw materials cost is actually lower for the furan route. The conversion of furan into butanol appears promising. 
Table 1. Cost Comparison for n-Butanol

Basis: 1995 dollars; $200 \times 10^{6} \mathrm{lb} / \mathrm{yr}$ plant capacity;

U.S. Gulf Coast location

\begin{tabular}{lcc}
\hline & $\begin{array}{c}\text { Hydrocarbon Route } \\
\text { from Propylene }\end{array}$ & $\begin{array}{c}\text { Furfural Route } \\
\text { from Furan }\end{array}$ \\
\hline $\begin{array}{ccc}\text { Capital Cost }\left(\$ 10^{6}\right) \\
\text { Battery limits }\end{array}$ & 100 & 90 \\
$\begin{array}{l}\text { Offsites } \\
\text { Total fixed investment }\end{array}$ & $\frac{50}{150}$ & $\frac{45}{135}$ \\
Working capital & 13.82 & 15.30 \\
Production Cost (\$/unit output) & & \\
\hline Net raw materials & $0.43^{\mathrm{a}}$ & $0.31^{\mathrm{a}, \mathrm{b}}$ \\
Total utilities & 0.01 & 0.17 \\
Total operating cost & 0.04 & 0.03 \\
Total overhead & 0.04 & 0.03 \\
Total cost of production & 0.52 & 0.54 \\
Total Cost + Depreciation & 0.67 & 0.68 \\
Selling Price (at $15 \%$ DCF) & 0.88 & 0.88 \\
\hline
\end{tabular}

adjusted for rounding error.

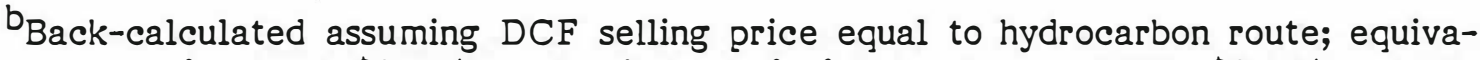
lent to furan at $\$ 0.25 / \mathrm{lb}$. Equivalent furfural values: $1995, \$ 0.18 / \mathrm{lb} ; 1982$, $\$ 0.08 /$ lb.

Butadiene. Table 2 summarizes the capital and production costs for butadiene produced by dehydration/dehydrogenation of tetrahydrofuran. It is clear that even as the cost of tetrahydrofuran is decreased to zero, the THF route can never be competitive under the assumed prices with conventional butadiene recovery from the by-product streams of an olefin plant. The estimated market value of butadiene will be at most $\$ 0.80 / 1 \mathrm{~b}$ in 1995 . Since $1.4 \mathrm{lb}$ of THF are required to produce $\mathrm{llb}$ of butadiene, any THF value above zero greatly increases the cost of raw materials and all related components. It is improbable that this process would ever be a viable way to upgrade by-product furfural. 
Table 2. Cost Comparison for Butadiene

Basis: 1995 dollars; $500 \times 10^{6} \mathrm{lb} / \mathrm{yr}$ plant capacity;

U.S. Gulf Coast location

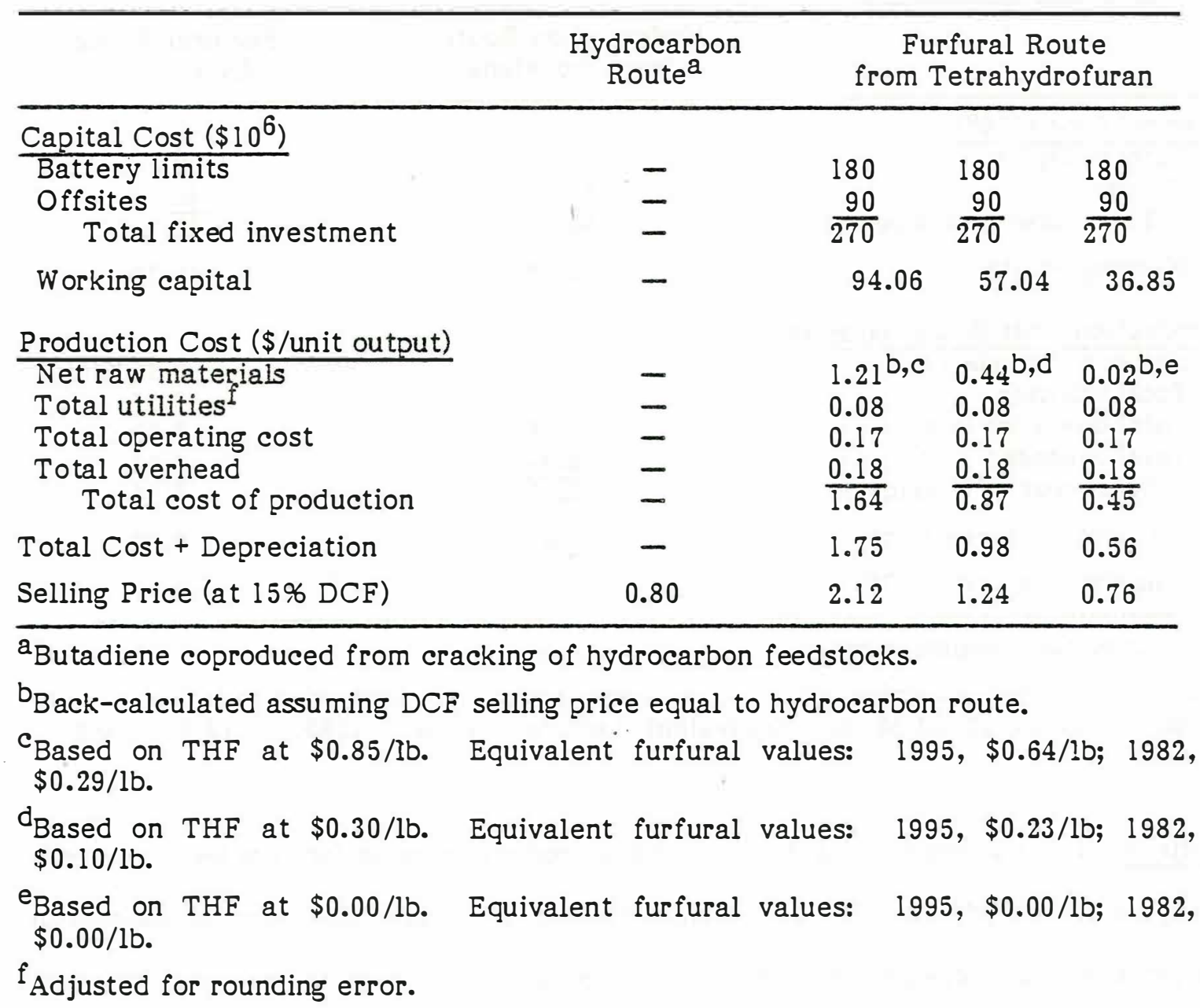

Styrene. The capital and operating costs for production of styrene via benzene alkylation/ethylbenzene dehydrogenation and via butadiene dimerization are shown in Table 3. The furfural route is based on butadiene produced from $\$ 0.00 / 1 b$ furfural. The estimated total fixed investments in 1995 for both processes are over $\$ 300$ million. The working capital required for the furfural route is almost twice as high as that for the hydrocarbon route. Primarily because the feed requirement for the furfurai route is almost $1.3 \times 10^{9} \mathrm{lb}$ of butadiene, the production cost and selling price of styrene from the dimerization process are significantly higher than those for the benzene process. 
Table 3. Cost Comparison for Styrene

Basis: 1995 dollars; 1 × $10^{9} \mathrm{lb} / \mathrm{yr}$ plant capacity;

U.S. Gulf Coast location

\begin{tabular}{|c|c|c|}
\hline & $\begin{array}{l}\text { Hydrocarbon Route } \\
\text { from Benzene }\end{array}$ & $\begin{array}{l}\text { Furfural Route } \\
\text { from Butadiene }\end{array}$ \\
\hline \multicolumn{3}{|l|}{ Capital Cost $\left(\$ 10^{6}\right)$} \\
\hline Battery limits & 215 & 240 \\
\hline Offsites & 90 & 75 \\
\hline Total fixed investment & $\overline{305}$ & $\overline{315}$ \\
\hline Working capital & 62.25 & 123.37 \\
\hline \multicolumn{3}{|l|}{ Production Cost ( $\$ /$ unit output) } \\
\hline Net raw materials & 0.53 & $0.96^{a, b}$ \\
\hline Total utilities & 0.03 & 0.10 \\
\hline Total operating cost & 0.01 & 0.02 \\
\hline Total overhead & 0.01 & 0.02 \\
\hline Total cost of production & $\overline{0.58}$ & $\overline{1.10}$ \\
\hline Total Cost + Depreciation & 0.65 & 1.16 \\
\hline Selling Price (at 15\% DCF) & 0.78 & 1.37 \\
\hline
\end{tabular}

$a_{\text {Adjusted for rounding error. }}$

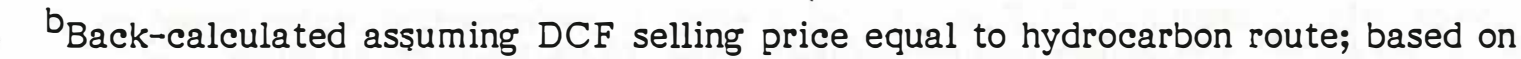
buțadiene at $\$ 0.76 / \mathrm{lb}$. Equivalent furfural value: $1995, \$ 0.00 / \mathrm{lb}$.

Adipie Acid. Process economics for the production of $200 \times 10^{6} \mathrm{lb} / \mathrm{yr}$ of adipic acid from cyclohexane oxidation and tetrahydrofuran oxidation are summarized in Table 4 . The estimated investment cost for the THF route is about $27 \%$ lower than the cost of the cyclohexane process. One reason is that the THF process is based on conventional oxo technology. The lower investment cost means that, even though the raw materials costs are higher, the working capital, total production cost, and selling price for the THFderived adipic acid are the same as for the cyclohexane-derived product. Adipic acid from THF offers substantial promise for future development. 
Table 4. Cost Comparison for Adipic Acid

Basis: 1995 dollars; $200 \times 10^{6} \mathrm{lb} / \mathrm{yr}$ plant capacity;

U.S. Gulf Coast location

\begin{tabular}{lcc}
\hline & $\begin{array}{c}\text { Hydrocarbon Route } \\
\text { from Cyclohexane }\end{array}$ & $\begin{array}{c}\text { Furfural Route } \\
\text { from Tetrahydrofuran }\end{array}$ \\
\hline Capital Cost $\left(\$ 10^{6}\right)$ & 110 & 75 \\
\hline $\begin{array}{c}\text { Battery limits } \\
\text { Total fixed investment }\end{array}$ & $\frac{55}{165}$ & $\frac{55}{130}$ \\
Working capital & 18.88 & 18.36 \\
Production Cost (\$/unit output) & & $0.59^{a, b}$ \\
Net raw materials & 0.48 & 0.11 \\
Total utilities & 0.12 & 0.03 \\
Total operating cost & 0.04 & 0.03 \\
Total overhead & 0.05 & 0.76 \\
$\quad$ Total cost of production & 0.69 & 0.89 \\
Total Cost + Depreciation & 0.86 & 1.11 \\
Selling Price (at 15\% DCF) & 1.12 & \\
\hline a Adjusted for rounding error. & & $1995, \$ 0.64 /$ lb; $1982, \$ 0.29 / 1 b$.
\end{tabular}

Maleic Anhydride. Table 5 compares the economics for the production of maleic anhydride by butane oxidation and by furan oxidation. The estimated investment costs for either process are the same, and the working capital requirements are only about $\$ 7$ million/yr. There are only minor differences in the front-end processing, which justifies the assumption that the two plants should cost the same. At a furan value of $\$ 0.30 / 1 \mathrm{~b}$ (a 1982 furfural value of $\$ 0.10 / \mathrm{lb}$ ), the raw materials costs and the production costs compare favorably with the butane process.

\section{Summary of Results}

The results of the process engineering studies performed by Energy Technology Associates indicate that three of the five furfural-based process routes could, with further research and development, compete commercially with existing hydrocarbonbased routes. The estimated 1982 and 1995 breakeven furfural values that could be 
credited to production of ethanol by cellulose hydrolysis are shown below for each promising process:

- Furan hydrogenation to n-butanol (furfural value: $1982, \$ 0.08 / \mathrm{lb} ; 1995, \$ 0.18 / \mathrm{lb}$ )

- Tetrahydrofuran carbonation to adipic acid (furfural value: 1982, \$0.10/1b; 1995, $\$ 0.21 / 1 b)$

- Furan oxidation to maleic anhydride (furfural value: 1982, $\$ 0.29 / 1 \mathrm{~b} ; 1995$, $\$ 0.64 / \mathrm{lb})$.

Table 5. Cost Comparison for Maleic Anhydride Basis: 1995 dollars; $60 \times 10^{6} \mathrm{lb} / \mathrm{yr}$ plant capacity; U.S. Gulf Coast location

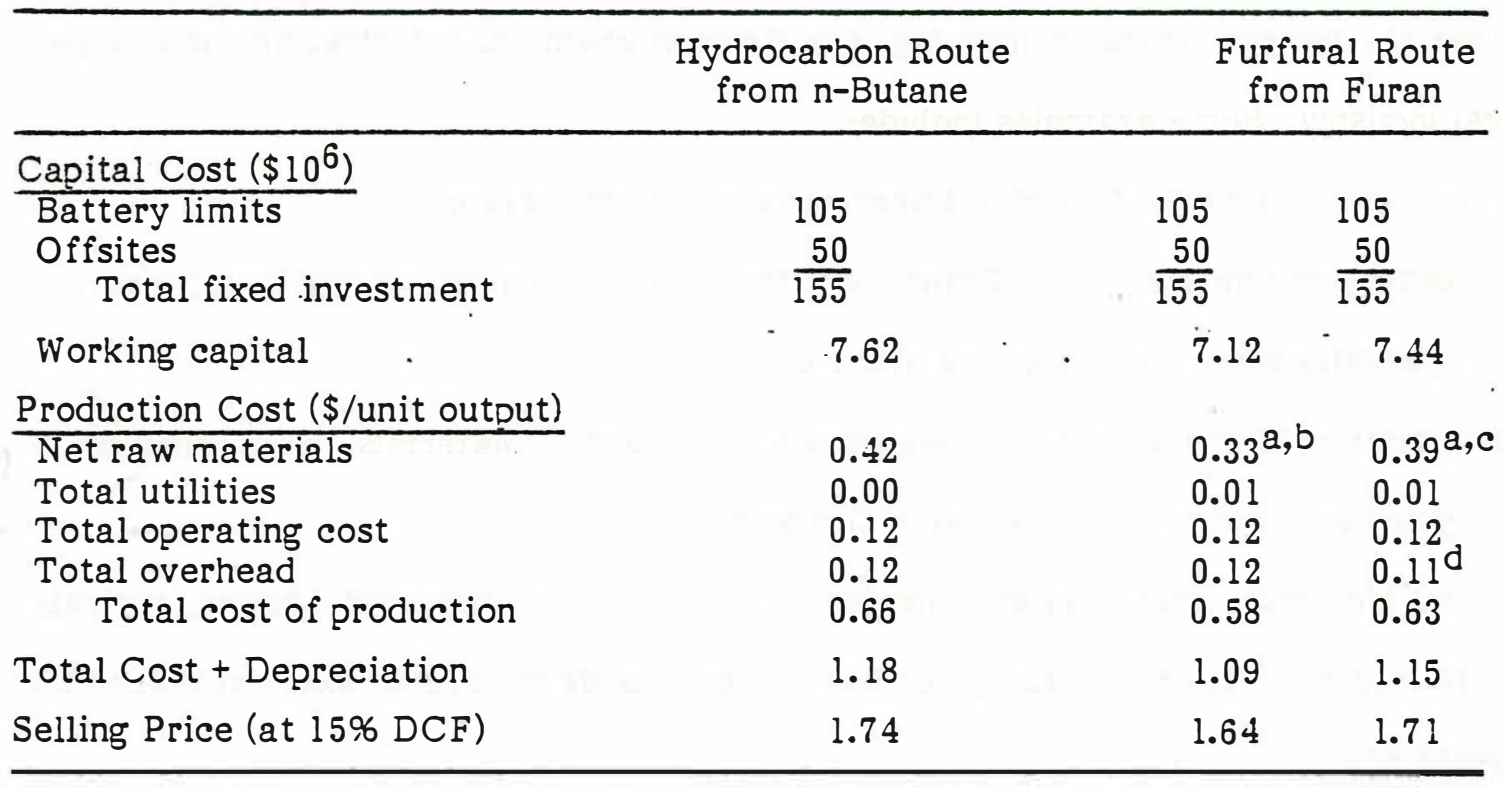

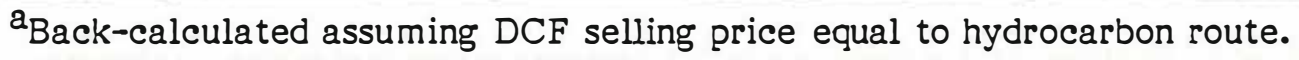

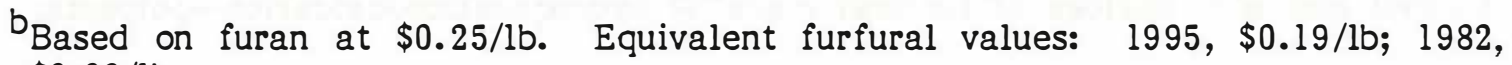
$\$ 0.08 / \mathrm{lb}$.

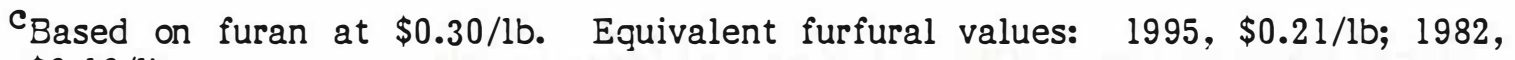
$\$ 0.10 / 1 b$.

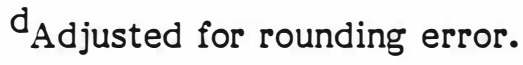

If a marginal 1982 furfural value of $\$ 0.08 / 1 b$ is assumed, the adipic acid process shows the greatest promise. However, considering the accuracy of the estimates and calculations, all three processes are viable candidates for additional study. The other two 
routes-tetrahydrofuran to butadiene and butadiene to styrene-do not have promising commercial potential, chiefly because the raw material costs for these processes are too high.

The combined production of n-butanol, adipic acid, and maleic anhydride in 1982 was approximately $2.3 \times 10^{9} \mathrm{lb}$, indicating vast markets are potentially available to acid hydrolysis-derived furfural. However, as is examined in the following section, factors within the complex structure of the petrochemical industry can restrict or augment the extent to which the conversion from hydrocarbon-based routes to furfural-based routes would probably occur.

Other opportunities for upgrading furfural have been recognized for many years and have been studied by the paper industry, the German chemical industry, and the petrochemical industry. Some examples include:

- 1,4-butanediol via THF-a plasticizer and resin intermediate.

- $\quad \gamma$-butyrolactone via THF. Typical applications are, among others, as a precursor of synthetic blood plasma and of nylon-4.

- Polymers of furfural and furan-synthetic lubricants. Materials for specific military applications were developed in Germany in the 1930s.

- Levulinic acid from furfural alcohol or HMF-a polymer and pharmaceuticals intermediate. A large family of derivatives was developed in extensive work 30 years ago.

- Alcohol and acid analogs of furfural made by hydrogenation/oxidation-polyester intermediates.

- Thermal decomposition of HMF to furfural and formaldehyde.

None of this work is new, but all of it could provide starting points for continuing investigation of the furfural market potential. 


\section{IMPLICATIONS OF AN EXPANDED FURFORAL MARKET}

The process studies described in the previous section establish an initial estimate of the potential demand for furfural as a chemical precursor. The prices listed in Table 6 are the prices that allow the furfural process design to be competitive with the conventional process. The quantities of furfural are those necessary to fill the 1982 demands for the given chemicals.

Table 6. Potential Furfural Demand

\begin{tabular}{llc}
\hline \multicolumn{1}{c}{ Market } & Price $(\$ / \mathrm{lb})$ & Quantity $\left(10^{6} \mathrm{lb}\right)$ \\
\hline Furfural & $\$ 0.50^{\mathrm{a}}$ & 140 \\
Adipic acid & $\$ 0.29$ & 1002 \\
Maleic anhydride & $\$ 0.10$ & 454 \\
Butanol & $\$ 0.08$ & 1758 \\
\hline
\end{tabular}

${ }^{a}$ This is a very conservative assumption since, at the current price of $\$ 0.66 / \mathrm{lb}$, profit margins are extremely low.

Although this information is important, breakeven process designs do not ensure that firms will adopt the furfural-based processes. This section discusses the additional factors affecting a firm's decision to switch to a new process. In this section we also examine the effects of the potential supply of ethanol from lignocellulosic feedstocks at the level of the petrochemical industry, and we determine the impact of credits earned from the sale of furfural.

\section{The Structure and Behavior of Petrochemical Markets}

Because chemical plants and oil refineries produce a fixed slate of products from various feedstocks, the price of any one product is not determined in isolation. The selling prices of the slate of products are jointly determined to best meet management 
objectives for the plant as a whole. Any one price must be considered in a larger integrated-market context: changes in the market may imply changes in the price of one product, which in turn may cause changes in related product prices.

A firm's reaction to increased competition for one of its products will be governed by the technology flexibility, the marginal cost of production, and the overhead costs to be shared by all the products sold by the firm. If other coproduct prices can be increased to cover overhead and a targeted rate of return, the firm can react to increased competition in one market by lowering its price to a point where marginal cost is just covered. In cases of coproduction, the secondary products are effectively (in an accounting sense) produced at no cost to the firm, and severe price competition could drive the price below the marginal production cost or so low that total revenues (from all products) decline. Such price adjustments of products can be expected to persist until competition in one market or in several markets increases sufficiently to require an adjustment of the amount or type of feedstock or the conversion process used by the plant. For a more accurate picture of the potential of new processes and products, these price, quantity, and process adjustments must be taken into consideration.

\section{Oil Refinery Structure and Behavior}

Oil refineries supply most of the feedstocks for the conventional processes of production of the chemicals considered in this study. This section discusses the effects of the competition between conventional and furfural-based processes on these refineries.

Refineries maximize their revenue by attempting to derive the optimal mix of products from the crude oil processed. The refinery can vary the type of crude oil processed or the secondary processing steps as the demands for fuels and chemicals vary. From any given configuration of type of crude oil and processing steps, the refinery produces a fixed slate of several products. The best-known example of refinery 
adjustment in response to changing demand is the seasonal swing between cracking heavy residual oil for enhanced gas production in summer and using the residual for heating oil in the winter.

The degree to which a chemical plant is capable of meeting its demands with a new technology or mix of technologies will determine whether the firm will reduce its general level of demand for petroleum feedstocks or simply demand less of one specific feedstock and possibly more of another. Neither of these situations have much impact on the refinery, since petrochemical demands account for only about $4.5 \%$ of total refinery output (12). If furfural displaces only small amounts of refinery feedstocks, refinery product prices or processing steps will change only marginally.

In the wider context of ethanol/furfural coproduction by cellulose hydrolysis, however, potential impacts on the refinery become more apparent. Ethanol is used both as a blender, reducing gasoline demand, and as a precursor for chemicals, thereby reducing the demand for petrochemical feedstocks. Methanol is also a source of blending components and chemical products and may further reduce the demand for petroleum products. Thus it may be possible to replace almost all the primary products of the refinery. Refineries may respond to these changing demands by reducing the number of barrels of oil refined. From an energy conservation perspective, the new technology has greater value if products such as furfural and ethanol reduce the number of barrels refined than if a readjustment in utilization of refinery products results.

\section{The Structure and Base-Case Values of the PETNET Model}

The PETNET model (11) was designed to represent the existing structure of the U.S. petrochemical markets. PETNET, in conjunction with an optimization computer code, can describe the optimal allocation of resources in the petrochemical industry and predict the response of plants and refineries to the new technologies considered in this paper. This section describes the operation and structure of PETNET. 
The PETNET model has three major components: final demands, supplies, and arcs or structural relationships that represent conversion processes. An optimal solution of the model is defined as the least-cost method of filling final demands, given the availability of resources and the structural ties linking supplies to demands. The magnitudes of the supplies and demands are fixed for any one simulation but may be varied for different scenarios. The arcs or structural relationships specify alternative routes for conversion of supplies to fill demands.

The U.S. petrochemical and fuel industry is represented in the model by the demands for 29 chemical and fuel products, which are listed in Table 7. Chemical demands represent major products that are inputs to final demand production processes with base-case values representative of 1982 levels of consumption. The fuel demands are also representative of the 1982 market; they include gasoline and the major fuel extenders and octane enhancers. The fuel demands also include ethanol, which is currently derived from starch fermentation processes, and methanol, which is produced from natural gas.

In the model, feedstocks may be derived from renewable or nonrenewable sources. Base-case supplies and prices of the nonrenewable feedstocks are presented in Table 8 along with approximate 1982 consumption. To determine the availability of oil-derived fuel and petrochemical supplies, we applied data on the average product yields per barrel of oil (1) to estimate the amount of oil refined. The model includes natural gas and natural gas product supplies to represent the feedstocks available for production of final demand products. The supplies include the "heavy" portions such as distillates and residuals, although in its current configuration the model does not include final demands for products that utilize these feedstocks. 
Table 7. Base-Case Fuels and Chemicals Final Demands

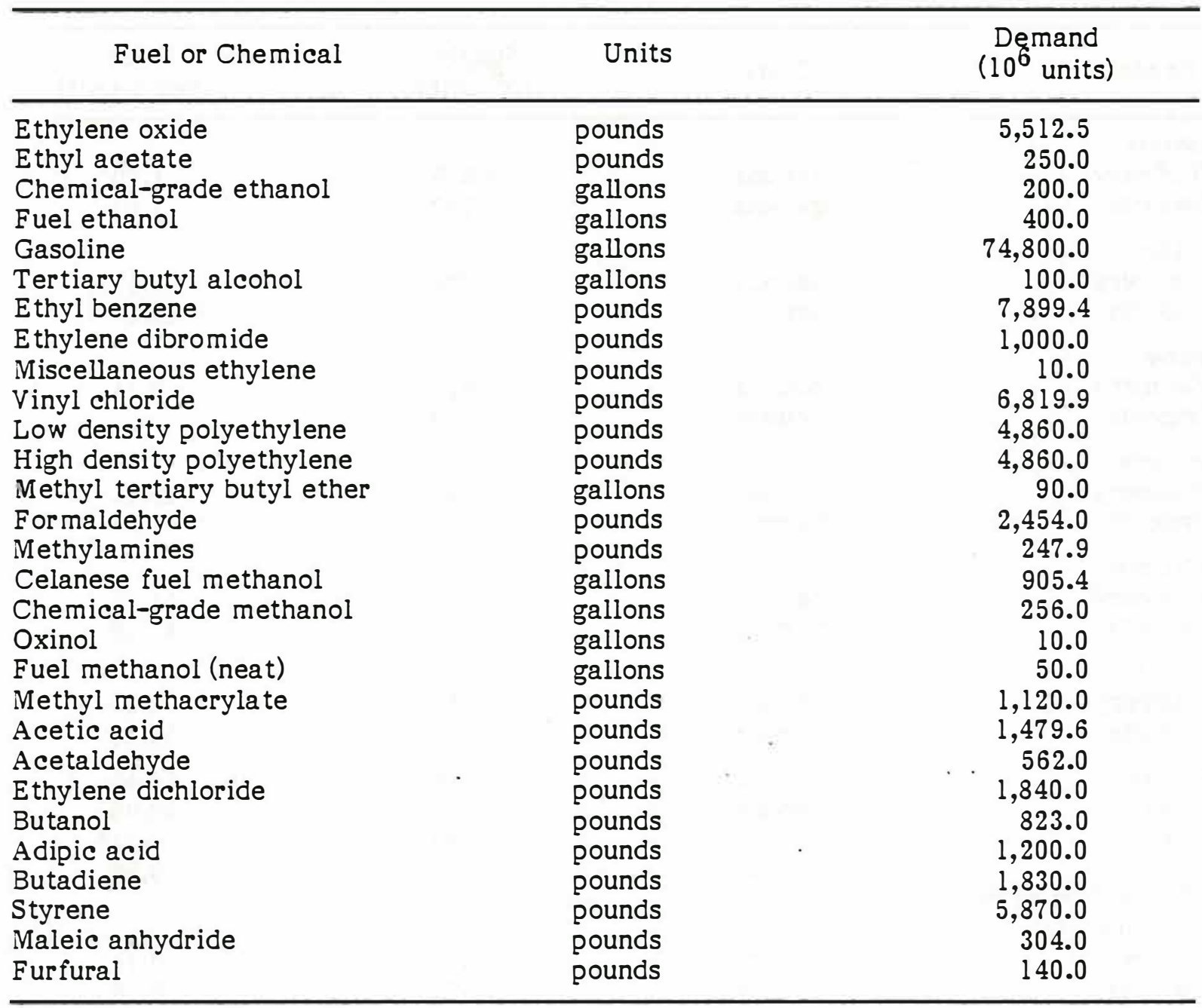

The base-case supplies and prices of renewable resources are presented in Tables 9 and 10, respectively. The supplies and prices of the two major categories-corn grain and lignocellulose-are broken down into the amounts for the 10 federal census regions so that it is possible to derive information from the model about the optimal feedstock combinations. Moreover, the regional structure makes possible analyses of where a renewable industry might emerge, given the specific feedstocks available and the product demands. 
Table 8. Base-Case Nonrenewable Feedstock Supplies and Prices

\begin{tabular}{|c|c|c|c|}
\hline Feedstock & Units & $\begin{array}{l}\text { Supply } \\
\text { (106 units) }\end{array}$ & $\begin{array}{c}\text { Price } \\
\text { (1982 \$/unit) }\end{array}$ \\
\hline \multicolumn{4}{|l|}{ Gasoline } \\
\hline Refinery & gallons & 79,615 & 1.00 \\
\hline Imports & gallons & 2,792 & 1.01 \\
\hline \multicolumn{4}{|l|}{ Jet fuel } \\
\hline Refinery & barrels & 284 & 45.15 \\
\hline Imports & barrels & 4 & 45.57 \\
\hline \multicolumn{4}{|l|}{ Ethane } \\
\hline Refinery & pounds & 7,825 & 0.11 \\
\hline Imports & pounds & 0 & \\
\hline \multicolumn{4}{|l|}{ Kerosene } \\
\hline Refinery & barrels & 52 & 45.15 \\
\hline Imports & barrels & 5 & 45.57 \\
\hline \multicolumn{4}{|l|}{ Distillate } \\
\hline Refinery & barrels & 963 & 41.87 \\
\hline Imports & barrels & 34 & 42.29 \\
\hline \multicolumn{4}{|l|}{ Residual } \\
\hline Refinery & barrels & 516 & 34.27 \\
\hline Imports & barrels & 272 & 34.69 \\
\hline Naphtha. & barrels & 346 & 46.45 \\
\hline Gas oil & barrels & 31 & 42.00 \\
\hline Propane & pounds & 4,100 & $0.1 \cdot 15$ \\
\hline Butane & pounds & 812 & 0.26 \\
\hline \multicolumn{4}{|l|}{$\begin{array}{l}\text { LPG (liquified petro- } \\
\text { leum gas) }\end{array}$} \\
\hline Refinery & pounds & 16,615 & 0.15 \\
\hline Imports & pounds & 13,828 & 0.16 \\
\hline $\begin{array}{l}\text { Miscellaneous refinery } \\
\text { products }\end{array}$ & barrels & 447 & 20.00 \\
\hline Natural gas & $\operatorname{sef}$ & $18,000,000$ & 0.003 \\
\hline
\end{tabular}

Process routes link the available feedstocks to the exogenous demands. That is, the model seeks to fill exactly the expressed final demands by utilizing the availabie production processes and feedstocks. The optimizing criterion applied in choosing the structure of the industry is cost minimization. All processes are represented by an input-output coefficient or yield of product per unit of feedstock, the unit cost (operations, capital changes, and profit margin), and capacity. To find the solution that will fill final 
demands at the lowest cost, the model considers relative production costs and allocates production according to the least-cost principle, taking constraints on feedstocks or production capacity into account.

Table 9. Base-Case Supplies of Renewable Lignocellulose and Corn Grain Feedstocks by Region

\begin{tabular}{|c|c|c|c|c|c|c|}
\hline \multirow{2}{*}{$\begin{array}{l}\text { Federal } \\
\text { Region }\end{array}$} & \multirow{2}{*}{$\begin{array}{l}\text { Corn } \\
\text { Residues } \\
\left(10^{6} t\right)^{b}\end{array}$} & \multicolumn{2}{|c|}{ Logging Residues ${ }^{a}$} & \multirow{2}{*}{$\begin{array}{l}\text { Growing } \\
\text { Wood } \\
\left(10^{6} \mathrm{t}\right)^{\mathrm{c}, \mathrm{d}}\end{array}$} & \multirow{2}{*}{$\begin{array}{c}\text { Total } \\
\text { Lignocellulose } \\
\left(10^{6} \mathrm{t}\right)\end{array}$} & \multirow{2}{*}{$\begin{array}{c}\text { Corn } \\
\text { Grain } \\
\left(10^{6} \text { bu }\right)^{e}\end{array}$} \\
\hline & & $\begin{array}{l}\text { Sof twood } \\
\left(10^{6} t\right)^{c}\end{array}$ & $\begin{array}{l}\text { Hardwood } \\
\left(10^{6} t\right)^{c}\end{array}$ & & & \\
\hline I & 0 & 1.734 & 1.464 & 49.1 & 52.298 & 0 \\
\hline II & 0.950 & 0.253 & 0.851 & 22.6 & 24.654 & 56.045 \\
\hline III & 3.900 & 0.640 & 5.731 & 84.6 & 94.871 & 241.976 \\
\hline IV & 6.460 & 5.950 & 8.726 & 201.5 & 222.636 & 444.260 \\
\hline V & 50.550 & 0.406 & 2.569 & 66.7 & 120.225 & 3302.790 \\
\hline VI & 2.030 & 2.504 & 3.015 & 83.4 & 90.949 & 160.818 \\
\hline VII & 38.330 & 0.009 & 0.558 & 15.2 & 54.097 & 2547.050 \\
\hline VIII & 4.260 & 1.299 & 0.011 & 32.5 & 38.07 & 275.261 \\
\hline IX & 0.530 & 3.509 & 0.314 & 31.4 & 35.753 & 41.156 \\
\hline $\mathrm{X}$ & 0.080 & 12.323 & 0.918 & 102.0 & 115.321 & 12.493 \\
\hline Total & 107.09 & 28.627 & 24.157 & 689.0 & 848.874 & 7081.849 \\
\hline
\end{tabular}

a SERI calculations based on data from the following sources: (9); (20); (22); USDA 1981 (23); (24).

${ }^{b}$ Max et al. 1983. Based on 1979 agricultural census data. Green (wet) tons at approximately $30 \%$ moisture.

$c_{\text {Green tons. }}$

dCalculated as $2 \%$ of total growing biomass estimated by U.S. Forest Service, (23).

$e_{1979}$ agricultural census data for approximately $15 \%$ moisture.

$\mathrm{f}_{\mathrm{I}}=$ Maine, New Hampshire, Vermont, Massachusetts, Rhode Island, Connecticut. $\Pi=$ New York, New Jersey. III = Pennsylvania, Maryland, Deleware, West Virginia. IV = Kentucky, Tennessee, North Carolina, South Carolina, Mississippi, Alabama, Georgia, Florida. V = Ohio, Michigan, Indiana, Illinois, Wisconsin, Minnesota. VI $=$ New Mexico, Oklahoma, Texas, Louisiana, Arkansas. VII = Nebraska, Kansas, Iowa, Missouri. VIII $=$ South Dakota, North Dakota, Montana, Wyoming, Colorado, Utah. IX = Arizona, Nevada, California, Utah, Hawaii. $\mathrm{X}=$ Idaho, Oregon, Washington, Alaska.

A list of conventional process routes included in the model is presented in Table 11. To these currently exercised routes, several alternative production processes, including the furfural routes identified in our discussion of the process studies, have been 
added. As indicated, the model includes several options, and each is subject to regional feedstock price diversity and resource constraints.

Table 10. Base-Case Renewable Lignocellulose and Corn Grain Prices by Region ${ }^{2}$

\begin{tabular}{lccccc}
\hline Region & $\begin{array}{c}\text { Corn } \\
\text { Residues } \\
(\$ / \mathrm{t})\end{array}$ & $\begin{array}{c}\text { Loftwood } \\
(\$ / \mathrm{t})\end{array}$ & $\begin{array}{c}\text { Hardwood } \\
(\$ / \mathrm{t})\end{array}$ & $\begin{array}{c}\text { Growing } \\
\text { Wood } \\
(\$ / \mathrm{t})\end{array}$ & $\begin{array}{c}\text { Corn } \\
\text { Grain } \\
(\$ / \mathrm{bu})\end{array}$ \\
\cline { 3 - 6 } & NA & 24.10 & 21.39 & 30.00 & 3.00 \\
I & 25.00 & 24.10 & 21.39 & 30.00 & 3.00 \\
II & 25.00 & 24.10 & 21.39 & 30.00 & 3.00 \\
III & 30.00 & 25.41 & 20.85 & 30.00 & 3.00 \\
IV & 20.00 & 24.10 & 21.39 & 30.00 & 3.00 \\
V & 40.00 & 25.41 & 20.85 & 30.00 & 3.00 \\
VI & 20.00 & 24.10 & 21.39 & 30.00 & 3.00 \\
VII & 25.00 & 21.48 & 21.79 & 30.00 & 3.00 \\
VIII & 25.00 & 21.87 & 22.05 & 30.00 & 3.00 \\
IX & NA & 23.95 & 29.78 & 30.00 & 3.00 \\
X & NA & &
\end{tabular}

Sources: Max et al. (17) and SERI calculations based on sources listed in footnote a of Table 9.

${ }^{a}$ Prices are for green (wet) tons except for corn, which includes $15 \%$ moisture.

Before we analyze soecific cases, we will consider the base-case implications of the data. Because there is a lack of data on the supply functions for corn grain and growing wood, these feedstocks, the feedstock prices and yields are considered to be the same for all regions in this model. With the given feedstock cost and an assumed yield of 2.5 gal ethanol from each bushel of corn grain, the cost of ethanol from fermentation of grain in all regions is $\$ 1.84 /$ gal in the base case $(\$ 1.20 /$ gal feedstock cost and $\$ 0.64 /$ gal processing cost). The cost and yield of wood feedstocks, defined as $2 \%$ of growing tree stock, are $\$ 30 / \mathrm{t}$ and $20 \mathrm{gal} / \mathrm{t}$, respectively. Thus ethanol produced by acid hydrolysis of wood costs $\$ 2.05 / \mathrm{gal}$ ( $\$ 1.50 / \mathrm{gal}$ feedstock cost and $\$ 0.55 /$ gal production cost). 
Table 11. Conventional Petrochemical Process Routes Included in the PETNET Model

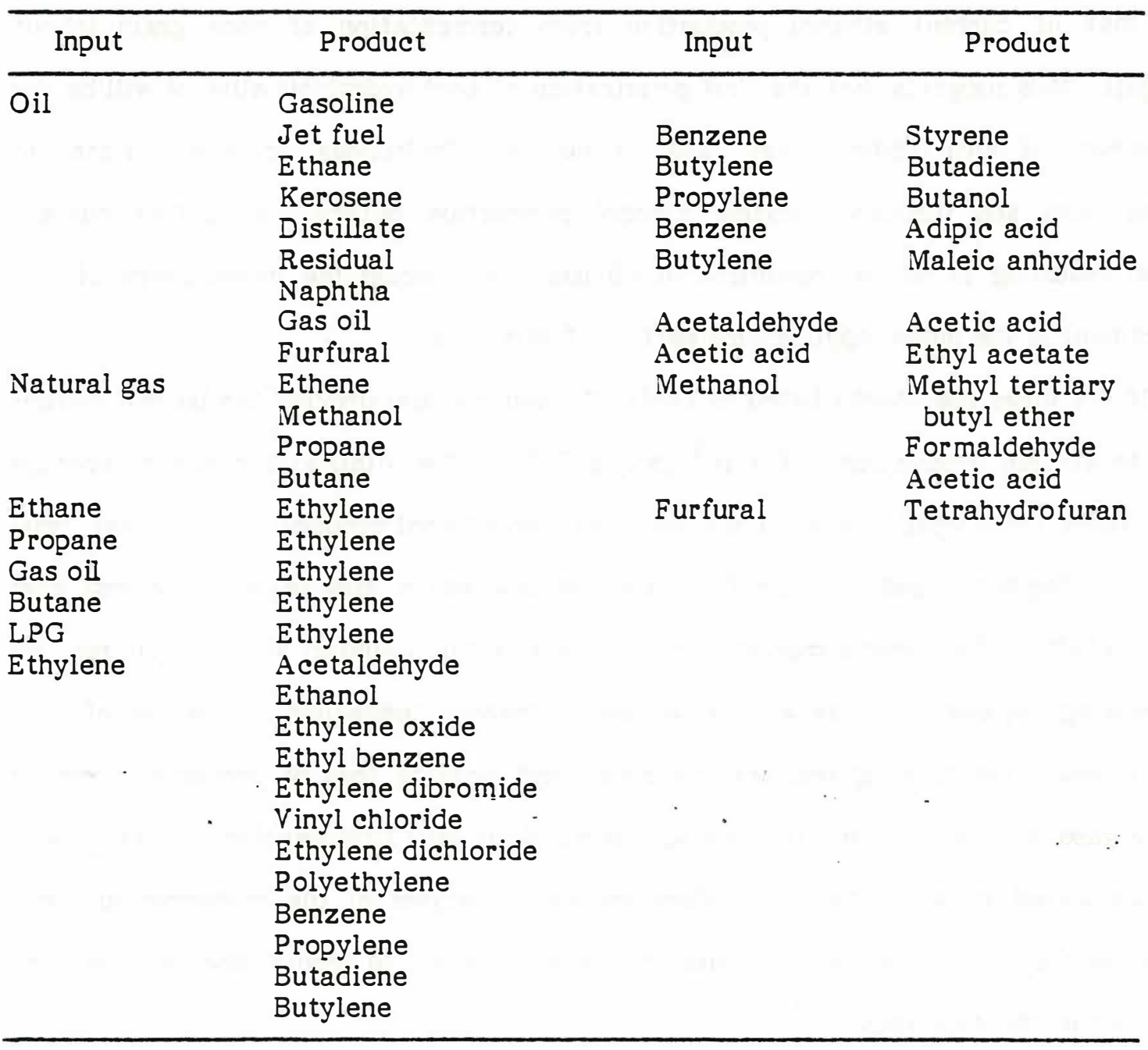

The diversity of other lignocellulosic feedstock supplies and prices (Tables 9 and 10) results in considerable diversity in the ethanol production costs. Given the base-case data, we can draw conclusions about the order in which the model will fill ethanol demands.

Regional ethanol production costs for acid hydrolysis processes using corn and logging residues are listed in Table 12. A total of almost $4 \times 10^{9}$ gallons of ethanol, at an average price of $\$ 1.36 /$ gal, could potentially be produced using current acid hydrolysis 
technology. Although this price is higher than the price of gasoline $(\$ 1.00 / \mathrm{gal})$, it is below that of current ethanol production from fermentation of corn grain (about $\$ 1.70 /$ gal). This suggests that the first penetration of acid hydrolysis ethanol will be the displacement of corn fermentation. That is, new acid hydrolysis capacity will tend to compete with and displace existing alcohol production before augmenting current supplies, resulting in no net reduction of oil use. We discuss the implications of this displacement in the model applications section of this paper.

Of the three feedstocks listed in Table 12, corn residues provide the largest contribution to ethanol production $\left(2.8 \times 10^{9} \mathrm{gal}\right.$, or $72 \%$ of the total $)$ at the lowest average ethanol price $(\$ 1.25 / \mathrm{gal})$. Most of the potential for ethanol production from corn residues is in Regions V and VI-the Corn Belt states-which also have the lowest cost sources $(\$ 20 / t)$. If extensive markets for ethanol could be found at about $\$ 1.20 / \mathrm{gal}$, the corn-growing regions could benefit from acid hydrolysis technology. The use of corn residues would increase agricultural revenues and provide locally produced fuels to displace gasoline. Acid hydrolysis industry most likely will first develop and eventually be concentrated in these regions. More in-depth analyses of the resources in these regions are required to refine the values presented here and to predict the local impacts and economic consequences.

Additional supplies of ethanol can be derived from logging residues but at higher average prices (Table 12) that are not substantially lower than current corn grain-based ethanol costs. The wide regional availability of these residues, however, suggests that ethanol production by acid hydrolysis could become widely dispersed and provide locally produced fuels in regions with low levels of grain production. 
Table 12. Base-Case Cost for Ethanol Production by Acid Hydrolysis of Corn and Logging Residues

\begin{tabular}{|c|c|c|c|c|c|c|c|c|}
\hline \multirow{3}{*}{ Region } & \multirow{2}{*}{\multicolumn{2}{|c|}{ Corn Residues }} & \multicolumn{4}{|c|}{ Logging Residues } & \multirow{3}{*}{$\begin{array}{c}\text { Regional } \\
\text { Weighted } \\
\text { Average } \\
\text { Price } \\
(\$ / \text { gal)c }\end{array}$} & \multirow{3}{*}{$\begin{array}{c}\text { Total } \\
\text { Available } \\
\text { Quantity } \\
\left(10^{6} \text { gal) }\right.\end{array}$} \\
\hline & & & \multicolumn{2}{|c|}{ Hardwood } & \multicolumn{2}{|c|}{ Softwood } & & \\
\hline & $\begin{array}{c}\text { Costa } \\
\text { (\$/gal) }\end{array}$ & $\begin{array}{l}\text { Quantityb } \\
\left(10^{6} \text { gal) }\right.\end{array}$ & $\begin{array}{l}\text { Cost }^{a} \\
\text { (\$/gal) }\end{array}$ & $\begin{array}{l}\text { Quantityb } \\
\text { (106 gal) }\end{array}$ & $\begin{array}{c}\text { Cost }^{a} \\
\text { (\$/gal) }\end{array}$ & $\begin{array}{l}\text { Quantity } \\
\left(10^{6} \text { gal) }\right.\end{array}$ & & \\
\hline I & - & - & 1.62 & 29.30 & 1.75 & 36.40 & 1.53 & 65.70 \\
\hline II & 1.39 & 24.70 & 1.62 & 17.02 & 1.75 & 5.06 & 1.51 & 46.78 \\
\hline III & 1.38 & 101.40 & 1.62 & 114.60 & 1.75 & 12.80 & 1.52 & 228.80 \\
\hline IV & 1.58 & 167.96 & 1.59 & 174.52 & 1.82 & 119.00 & 1.55 & 461.48 \\
\hline V & 1.19 & 1313.00 & 1.62 & 51.38 & 1.75 & 8.12 & 1.21 & 1372.50 \\
\hline VI & 1.96 & 52.78 & 1.59 & 60.30 & 1.82 & 50.08 & 1.78 & 163.16 \\
\hline VII & 1.19 & 996.58 & 1.62 & 11.16 & 1.75 & 0.18 & 1.19 & 1007.92 \\
\hline VIII & 1.38 & 110.76 & 1.64 & 0.22 & 1.62 & 25.98 & 1.43 & 136.96 \\
\hline IX & 1.38 & 13.78 & 1.65 & 6.28 & 1.64 & 70.18 & 1.60 & 90.24 \\
\hline $\mathrm{X}$ & - & - & 2.04 & 18.36 & 1.75 & 246.46 & 1.77 & 264.82 \\
\hline $\begin{array}{l}\text { Weighted } \\
\text { average } \\
\text { cost }\end{array}$ & 1.25 & 2780.96 & 1.62 & 483.14 & $\$ 1.75$ & 574.26 & 1.37 & 3838.36 \\
\hline
\end{tabular}

${ }^{a}$ Cost (\$/gal) of producing a gallon of ethanol by acid hydrolysis of the indicated feedstock. The cost includes the specific regional feedstock price, the conversion yield, and the conversion cost.

${ }^{b}$ The maximum quantity of ethanol that can be produced at the indicated cost, given base-case resource supplies.

${ }^{c_{W e i g h t e d}}$ (by quantities) average required cost per gallon of ethanol, assuming all feedstocks are fully utilized.

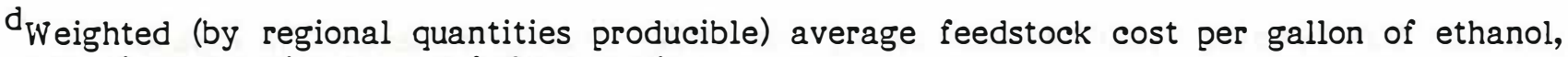
assuming all regions are at full production.

\section{Applications of PETNET}

The results obtained by runs of the PETNET model describe the optimal allocation of refinery products, natural gas, and biomass feedstocks in meeting fuel and chemical demands. Because of the promising results of the engineering analyses described in the process studies section, the furfural routes to butanol, adipic acid, and maleic anhydride have been included in PETNET. Varying the prices of feedstocks and conversion costs of the furfural and conventional routes not only allows the conclusions of the engineering data to be verified but also suggests the reactions of refineries and chemical plants to 
these changes. PETNET is also capable of predicting the response of the petrochemical markets to the levels of ethanol production corresponding to different levels of furfural production. Finally, by varying prices and process costs in the model, scenarios relating to the three levels of cost goals and technology transfer can be constructed and analyzed.

Fixed-Blend Ethanol Demands. To make a first approximation of the potential for market penetration by ethanol, the model was run with various levels of ethanol contribution to total transportation fuel demands. All feedstocks and process data were set at their base-case levels, thus, representing current technology and cost levels, and not considering furfural by-product credit. Total transportation fuel demand was held constant at $80 \times 10^{9} \mathrm{gal}$, and the ethanol contribution was progressively raised from $0.5 \%$ to $25 \%$ of the total amount. Additionally, for each case, the supply of oil and all oilderived products was reduced in proportion to the reduction in gasoline demand. Thus, these runs allow examination of the potential for substitution of ethanol for gasoline and an equivalent reduction in refinery demand for oil.

Table 13 presents the results of these fixed-blend cases for various sources of fuel ethanol. As expected, corn residues supply the initial ethanol demands; for ethanol contributions up to $2.5 \%\left(2 \times 10^{9} \mathrm{gal}\right)$, all ethanol is produced by the acid hydrolysis of corn residues. At the 5\% level, all logging residues are used and fermented corn grain fills the remaining demand. At the $10 \%$ level, wood comes into the solution as the limit (in the base case) of corn used for ethanol is reached. To meet the $25 \%$ level of ethanol contribution to vehicle fuels, all wood is exhausted and $13 \%$ of the available corn grain must be fermented to meet the $20 \times 10^{9}$ gal ethanol demand.* In all cases, the solution

*The base case constrains corn-derived ethanol to $10^{9}$ gal. To reach the $25 \%$ level of ethanol contribution, the constraint was relaxed, allowing all available corn grain (approximately $7 \times 10^{9} \mathrm{bu}$ ) to be used for ethanol if necessary. 
is feasible: all demands can be met even though oil and oil-derived products are reduced in proportion to the gasoline demand reduction. However, the structure of the industry changes somewhat to adjust to the changes in petrochemical feedstock availability. First, natural gas consumption increases to provide feedstocks for olefin production. Reduced oil availability reduces the supplies of oil-derived propane, butane, naphtha, etc., and natural gas refining must increase to make up the difference. Although the supplies of natural gas are more than sufficient to substitute for the reduced availabilities of petroleum products, forcing the model to utilize more expensive ethanol and natural gas makes it more expensive to fill final demands.

Table 13. Feedstock Contributions to Fixed-Blend Ethanol Demands ${ }^{a}$

\begin{tabular}{|c|c|c|c|c|c|c|}
\hline \multirow{2}{*}{ Feedstock } & \multicolumn{6}{|c|}{$\begin{array}{c}\text { Ethanol Contribution to } 80 \times 10^{9} \mathrm{gal} \\
\text { Fuel Demand }\end{array}$} \\
\hline & $0.5 \%$ & $1.25 \%$ & $2.5 \%$ & $5 \%$ & $10 \%$ & $25 \%$ \\
\hline $\begin{array}{l}\text { Corn residues } \\
\text { Logging residues }\end{array}$ & 400 & 1,000 & 2,000 & 2,720 & $2,784^{b}$ & $2,784^{b}$ \\
\hline Softwood & 0 & 0 & 0 & $574^{\mathrm{a}}$ & $574^{b}$ & $574^{b}$ \\
\hline Hardwood & 0 & 0 & 0 & 469 & $483^{a}$ & $483^{b}$ \\
\hline Wood & 0 & 0 & 0 & 0 & 3,160 & $13,77^{\mathrm{b}}$ \\
\hline Corn grain & 0 & 0 & 0 & 237 & $1,000^{b}$ & $2,381^{c}$ \\
\hline Total ethanol & $\overline{400}$ & $\overline{1,000}$ & $\overline{2,000}$ & 4,000 & 8,000 & 20,000 \\
\hline $\begin{array}{l}\text { Relative } \\
\text { objective function } \\
\text { value }\end{array}$ & 1.00 & 1.001 & 1.002 & 1.008 & 1.03 & 1.13 \\
\hline $\begin{array}{l}\mathrm{a}_{\text {Units of entries ar }} \\
\mathrm{b}_{\text {Resource at base- }} \\
\mathrm{c}_{\text {Base-case constr }} \\
\text { (approximately } 7 \\
\text { of corn-derived et }\end{array}$ & $\begin{array}{l}\text { e } 10^{6} \\
\text { case ce } \\
\text { aint } \\
\times 10^{9}\end{array}$ & $\begin{array}{l}\text { ethanol. } \\
\text { city. } \\
\text { axed, a }\end{array}$ & owing & all av & $\begin{array}{l}\text { able } c \\
\text { essary. } \\
\text { nately }\end{array}$ & $\begin{array}{l}\text { grain } \\
\text { he level } \\
6 \text { of the }\end{array}$ \\
\hline
\end{tabular}

The relative objective function value over these cases provides a rough estimate of the cost of forcing (e.g., by legislative mandate and curtailment of imports) the economy 
to substitute ethanol for gasoline and reducing oil consumption accordingly. The relative cost of meeting fuels and chemicals demands varies only slightly from the base case to the $5 \%$ ethanol contribution. Of course the average cost per gallon of fuel is increased because the cost of ethanol is greater than that of gasoline. However, at low levels of ethanol contribution, the low-cost routes to ethanol predominate, and the increment to average fuel cost is low. At higher levels of ethanol demand, more costly routes (wood and corn grain) are required, and the average fuel cost and total industry cost rise accordingly.

Free-Market Ethanol Demands. The analyses in the previous section involved determining the effect of increasing the pool of ethanol exogenously. That is, the system was forced to substitute ethanol for gasoline, and the results therefore pertain to forced market penetration. In the runs described in this section the free market is simulated; ethanol and gasoline compete for the (fixed) transportation fuel demand. The model seeks the minimum-cost solution for meeting final demands, given the alternative processes, feedstocks, and costs.

The results of two different experimental designs are reported below. In the first design natural gas and oil prices are varied to examine the effect of increased nonrenewable feedstock costs on the role of ethanol in the optimized economy. The second design addresses the benefits derived from technology improvements achieved through further R\&D that would expand ethanol fuel consumption: in particular, process yield improvement and feedstock cost reductions. Both of these experiments were run with two important constraints. The first relates to the role of fermentation ethanol. Currently, a production capacity of about $500 \times 10^{6}$ gal ethanol produced from fermentation of starch or sugar feedstocks is available. As demonstrated above, the first acid hydrolysis plants will probably compete with the existing plants using corn grain. However, to estimate the potential for supplementing current corn grain ethanol with acid hydrolysis capacity, the model is restricted to utilizing all $500 \times 10^{6}$ gal of corn grain capacity in 
all experiments. This allows examination of capacity-augmenting effects; but for this situation to materialize, corn fermentation plants would require a production subsidy (up to $\$ 1.00 / \mathrm{gal}$ ) or cheaper corn (as low as $\$ 0.50 / \mathrm{bu}$ ) to compete with corn residues in a proven commercial acid hydrolysis facility.

The second constraint involves the by-product credit for furfural. To derive a steady-state solution for the credit, the model was run with progessively lower furfural costs, starting at $\$ 0.29 / 1 b$, to determine the maximum furfural penetration. This occurred at $\$ 0.08 / 1 \mathrm{~b}$, where $2.48 \times 10^{8} \mathrm{lb}$ furfural are utilized. Given the fixedproportion production rate of $3.5 \mathrm{lb}$ furfural per gallon of ethanol, $710 \times 10^{6} \mathrm{gal}$ of ethanol can be subsidized by furfural at a rate of $\$ 0.28 / \mathrm{gal}$. According to the data in Table 12, the cheapest source of ethanol is corn residues. So, the model was supplied with $710 \times 10^{6} \mathrm{gal}$ of corn residue-based ethanol priced at $\$ 0.91$. Additional ethanol was unsubsidized and therefore priced at the base-case cost.

To summarize, the base case for the experiments reported below involves $500 \times 10^{6}$ gal of corn grain-based ethanol and $958 \times 10^{6}$ gal of furfural-subsidized corn residuebased ethanol. Additional penetration of ethanol can be ascribed to the particular parameters applied in a specific case.

\section{SUMMARY}

To summarize the impacts of a furfural credit on the selling price of ethanol and compare this research gain with the benefit derived from xylose fermentation, we have estimated supply curves. The effects of these R\&D options are evaluated in terms of the ability of these options to improve the competitive position of ethanol from the base case. 
The base-case supply curve (as shown as the uppermost curve in Figure 1) is constructed from the information in Table 13. The points along the supply curve show the quantities of ethanol that could be produced from lignocellulosic feedstocles and the corresponding ethanol selling prices. The curve is drawn as a step function because the prices of the feedstocks vary regionally and there are yield differences in the various feedstocks. The horizontal line segments measure the amounts of ethanol available at each price while the vertical line segments show the incremental price change required to make additional amounts of ethanol available. These price changes result from depletion of the least expensive feedstocks.

Figure 1 also shows in addition to the base-case curve three supply curves: the base case with a furfural credit, the base case with a $30 \%$ yield increase, and the base case with a $60 \%$ yield increase. Each case is discussed in greater detail below.

\section{The Furfural Credit}

With the assumptions of $3.5 \mathrm{lb}$ of furfural produced per gallon of ethanol at a selling price of $\$ 0.08 / \mathrm{lb}$, the ethanol production cost credit is $\$ 0.28 /$ gal. Since the size of the furfural market being considered is $3354 \times 10^{6} \mathrm{lb}$, the price of approximately $960 \times 10^{6} \mathrm{gal}$ of ethanol is reduced from $\$ 1.19 / \mathrm{gal}$ to $\$ 0.91 / \mathrm{gal}$ (reference line a in Figure 7). The impact of this shift is that almost $1.0 \times 10^{9}$ gal of ethanol (which is competitive as an octane enhancer at a price of $\$ 1.19 /$ gal) would be competitive as a neat fuel at a price of $\$ 0.91 / \mathrm{gal}$. At this price ethanol is more than marginally competitive as a neat fuel, a competitive position might be maintained at prices as high as $\$ 1.00 /$ gal. This implies substantial profit for the initial entrants into the production of ethanol and furfural. The furfural credit creates one additional step in the supply curve. Because there are no other changes, the base-case supply curve remains unchanged at ethanol levels greater than $960 \times 10^{6}$ gal. 
If additional markets for furfural could be developed, larger levels of ethanol production would earn a credit. Reference lines $b$ and $c$ show the effects of $100 \%$ and $200 \%$ increases in the size of the furfural market in terms of the larger levels of ethanol production that would earn a credit. Corresponding to a $100 \%$ increase in the size of the furfural market is a level of ethanol production that is less than the total ethanol available at $\$ 1.19 /$ gal. The effects of the furfural credit are therefore the same: ethanol that was competitive as an octane enhancer is now competitive as a neat fuel. At a $200 \%$ increase in the size of the furfural market, the balance of the lowest-cost ethanol is made competitive as a neat fuel and the next two more costly sources of ethanol, which were formerly not competitive as octane enhancers, become competitive as a result of the credit.

\section{Thirty Percent Increase in Ethanol Yield}

A $30 \%$ increase in ethanol yield might be achieved through research efforts in xylose fermentation or increased cellulose yield from the feedstocks. Since xylose fermentation is an alternative use of the xylose stream, no furfural credit can be applied in addition to the gains from the xylose fermentation. As opposed to the furfural credit, which only lowers the price of ethanol, the $30 \%$ increase in yield decreases prices and produces more ethanol. This causes the supply curve to shift down and to the right; just over $3 \times 10^{9}$ gal are competitive as a neat fuel and $10^{9}$ additional gal are competitive as octane enhancer as a result of the yield increase from xylose fermentation. If the $30 \%$ yield increase is the result of increased cellulose recovery, the shift of the supply curve is the same as that for xylose fermentation except that it is also possible to incorporate the different uses of the xylose fraction. The downward shift of this curve results from the effect of the $\$ 0.28 /$ gal furfural credit on the levels of ethanol production, as denoted by reference lines $a, b$, and $c$. Past point $c$, no credit is earned and the remainder of the supply curve is unchanged. As a result of the increased ethanol yield, the least-cost 
ethanol is now increased from about $2.3 \times 10^{9}$ gal to almost $3.0 \times 10^{9}$ gal. This allows the furfural credit earned from a $200 \%$ increase in the furfural market to be earned completely by the ethanol produced by the least-cost feedstock. In this case, the ethanol cost is lower than that from any other case, with $3 \times 10^{9}$ gal priced below $\$ 0.70 /$ gal. Again, since this ethanol could be priced close to $\$ 1.00 /$ gal, the furfural credit is a large source of profit for the producers of the first $3 \times 10^{9} \mathrm{gal}$ of ethanol.

In conclusion, it appears that furfural's best contribution will be as a source of intermediate-term profit for ethanol/furfural producers. This promise of profit should serve as a strong incentive in the develop ment and implementation of the acid hydrolysis technology. The maximum ethanol penetration in the longer term, however, will result from technologies capable of increasing ethanol yields.

\section{CONCLUSIONS AND RECOMMENDATIONS}

Furfural is an economically attractive coproduct in the acid hydrolysis of cellulose for fuel-grade ethanol production, provided large-volume markets can be developed. A single $50 \times 10^{6} \mathrm{gal} / \mathrm{yr}$ ethanol plant would produce 140 to $200 \times 10^{6} \mathrm{lb} / \mathrm{yr}$ of furfural, an amount equal to the total current domestic market. Thus, new outlets for furfural in substantial quantities would be needed to support large-scale development of an ethanolfrom-cellulose industry. Furfural is a versatile, reactive chemical with a history of utility as a precursor that predates the petrochemicals era. This study uncovered some of the old laboratory work on upgrading furfural and established its present-day economic potential as a large-volume, low-cost by-product $(2,10)$.

This study indicates a favorable economic prognosis for manufacture of n-butanol, adipic acid, and maleic anhydride from furfural. The information used to make the appraisals is old and of uncertain quality, and in no case did it extend beyond laboratory 
demonstrations of the chemical reactions. Nevertheless, the results indicate that these primitive processes have enough profitability potential to ultimately displace the conventional hydrocarbon-based processes and provide significant support to the economics of fuel-grade ethanol production.

Development of industrial production of n-butanol, adipic acid, and maleic anhydride from furfural could expand the furfural market to $3354 \times 10^{6} \mathrm{lb}$. The analysis of furfural potential, within the context of an optimally organized fuels and chemicals industry, indicates that these three most attractive processes could thus subsidize approximately $960 \times 10^{6} \mathrm{gal}$ of ethanol to a selling price as low as $\$ 0.91 / \mathrm{gal}$. This ethanol cost is based on a furfural credit of $\$ 0.28 / \mathrm{lb}$ and utilization of the lowest-cost biomass feedstocks (corn residues at $\$ 20 /$ ton). This production level exhausts slightly less than one-half of the available corn residues, the most economic feedstock for ethanol production. If additional furfural markets of about $5 \times 10^{9} \mathrm{lb}$, with a value of at least $\$ 0.08 / 1 \mathrm{~b}$, could be identified, then over $2.5 \times 10^{9}$ gal of ethanol could be marketed at about $\$ 1.00 /$ gal.

The phenolic resin market is another possible outlet for large quantities of furfural. Current domestic volume is $1.2-1.5 \times 10^{9} \mathrm{lb} / \mathrm{yr}$ with prices in the $\$ 2.00-\$ 2.50 / 1 \mathrm{~b}$ range. The market has been dominated since its beginning by phenol-formaldehyde formulations and has become firmly established on this foundation. Furfural, an aldehyde, can be substituted for formaldehyde to yield a different group of thermosetting phenolic resins. A related potential new product group could be furan resins, based on substitution of furfural alcohol (from furfural) for phenol. A large number of formulations were invented many years ago, but they remain undeveloped. It is possible that, given very low cost furfural, a new competitive line of phenolic resins would find a place in the market. However, estimates of such penetration are difficult because of the 
complex interactions of formulations, performance properties and prices, and the traditional and strong resistance of the resin business to changes. The place of furfural in the thermo-setting resin business was beyond the scope of this study.

Converting the xylose stream to ethanol has about the same effect on the selling price of ethanol as the furfural credit. The major difference between these two research options is the increased availability of ethanol derived from all feedstocks through xylose fermentation, while the furfural credit lowers only the price of ethanol derived from the cheapest feedstock (corn residues). However, the impact of xylose fermentation is restricted to the fuels markets, while the coproduction and sale of furfural not only makes ethanol more competitive, but also provides substitutes for other petroleum-based products that are chemical precursors. The greatest ethanol penetration will result from xylose fermentation, while the furfural credit offers large near-term profits as an incentive to ethanol producers and has a more diversified impact on reduced petroleum product demand.

\section{REFERENCES}

1. American Petroleum Institute, 1983, Basic Petroleum Data Book, Washington, D. C.: American Petroleum Institute.

2. British Intelligence Objectives Subcommittee, "Preparation of Adipic Acid from Tetrahydrofuran and Carbon Monoxide," BIOS 351, 1948.

3. Brownlee, H. J. and Miner, C. S., Ind. Eng. Chem. 40, 201 (1948).

4. Cass, O. W., Chemical Industries 60, 612 (1947).

5. Chemical and Engineering News, 11 (1983) May 2.

6. Chemical and Engineering News, 35 (1982) June 14.

7. Chemical Marketing Reporter, 4 (1982) Sept. 27. 
8. Chemical Marketing Reporter, (1983) May 16.

9. Cost, N. D. and McClure, J. P., Multiresource Inventories: Techniques for Estimating Biomass on a Statewide Basis, Kesearch Publication SE-228, 1982.

10. Dunlap, A. P. and Peters, F. N., The Furans, New York: Reinhold Publishing Corporation, 1953.

11. Farina, R., "Biomass Alcohols as Potential Petroleum Alternatives in the Fuel and Petrochemical Industries: A Generalized Network Model," unpublished dissertation, Boulder, CO: University of Colorado, 1982.

12. Gaines, L. L., et al., Energy and Materials Flows in the Production of Olefins and Their Derivatives, ANL/CNSU-9, Chicago, $\mathbb{L}$ : Argonne National Laboratory, 1980.

13. Gilliland, E. R. and Lavender, H. M., Jr., India Rubber World III (No. 1), 67 (1944).

14. Hasche, R. L., Chemical and Engineering News 23 (No. 20), 1840 (1945).

15. Johnson, R. C., et al., Chemicals from Wood: The Policy Imolications of Federal Subsidy II, MTR-83 W2-02, MeLean, VA: MITRE Corporation, 1983.

16. Kirshenbaum, I., "Butadiene," Encyclopedia of Chemical Technology, 3rd edition, Vol 4, edited by Kirk and Othmer, 313, 1978.

17. Max, W., et al., 1983, Feasibility of Using Agricultural Residues For Energy Production, unpublished internal technical report, Golden, CO: Solar Energy Research Institute.

18. McKillip, W. J., and Sherman, E., "Furan Derivatives," Encyclopedia of Chemical Technology, 3rd edition, Vol. 11, edited by Kirk and Othmer, 499, 1978.

19. Milas, N. A. and Walsh, W. L., J. Am. Chem. Soc. 57, 1389 (1935).

20. Monteith, D. B., The Availability of Forest Biomass in New York, Albany, NY: New York State Energy Office, 1981.

21 . Smith, H. A. and Fuzek, J. F., J Chem. Soc. 71, 415 (1949).

22. U.S. Department of Agriculture, "Forest Statistics of the United States, 1977," review draft, Washington, DC: USDA, 1978. 
23. U.S. Department of Agriculture, Tree Biomass: A State-of-the-Art Compilation, General Technical Report WO-33, Washington, DC: USDA, 1981.

24. U.S. Department of Agriculture, An Analysis of the Timber Situation in the United States 1952-2030, Forest Resource Report No. 23, Washington, DC: USDA, 1982. 